\title{
STRATEGIES OF LEGAL RUPTURE: THE POLITICS OF JUDGMENT
}

\section{Brenna Bhandar*}

In this article the author considers the meaning of a legal strategy of rupture, and the possibilities that such a strategy holds for anti-colonial and anti-capitalist political resistance. The strategy of rupture, developed by advocate Jacques Vergès, and theorised by Emilios Christodoulidis, provides the initial framework for thinking through how this mode of deploying law for political transformation could be developed into a general approach that is applicable not only in the criminal law context, but also, in other fields of law. Shifting from the strategies of advocates to the question of judgment, the author analyses a recent judgment of the Indian Supreme Court, and explores how legal judgments can affect political ruptures through re-defining concepts such as security with the interests of the most marginalised communities in mind. By re-defining concepts that are vital to protecting the rights of people to resist various forms of exploitation, and by re-investing rights with new meaning, the Indian Supreme Court in Sundar et al v State of Chattisgarh (July 5, 2011) charts a course that holds promise for the struggles of legal advocates elsewhere.

Dans le présent article, l'auteure se penche sur la signification d'une stratégie judiciaire de rupture et examine les possibilités qu'une telle stratégie recèle une résistance politique anticoloniale et anticapitaliste. La stratégie de rupture, élaborée par l'avocat Jacques Vergès et théorisée par Emilios Christodoulidis, fournit le cadre initial pour examiner soigneusement comment cette façon d'utiliser le droit à des fins de transformation politique pourrait déboucher sur une approche générale qui s'applique non seulement au contexte du droit criminel mais également à d'autres domaines du droit. Délaissant les stratégies de défense pour la question du jugement, l'auteure analyse un jugement récent de la Cour suprême indienne et examine la façon dont les décisions judiciaires peuvent affecter les ruptures politiques en redéfinissant des concepts tels que la sécurité tout en ayant à l'esprit les intérêts des collectivités les plus marginalisées. En

Queen Mary, University of London. I would like to express my sincere gratitude to Reem Bahdi, the audience at the 2011 Windsor Faculty of Law Annual Access to Justice Lecture, Jon Goldberg-Hiller, and an anonymous reviewer for their very helpful and insightful comments on an earlier draft of this article. 
redéfinissant des concepts qui sont cruciaux relativement à la protection du droit des personnes de résister à diverses formes d'exploitation, et en accordant une nouvelle signification à certains droits, la Cour suprême indienne, dans l'affaire Sundar et al v State of Chattisgarh (5 juillet 2011), trace une voie prometteuse pour les luttes des avocats d'autres régions $d u$ monde.

The subversion of law begins with the reduction of politics to a crime. After such subversion, the law becomes a pretext for violence. The liquidation of political dissent brings up the troubling erasure of the human rights of political dissenters.

\section{INTRODUCTION}

This article had its beginnings as a paper presented in July 2011 at an event organized by Decolonising Architecture Art Residency, in Beit Sahour, Palestine. The event was titled "Strategies of Legal Rupture" and its aim was to consider how legal strategies could be utilized to subvert the colonial legal order. Is it possible, for instance, to conceive of a legal action that might challenge the very legitimacy of the Israeli colonial legal order itself, through a discrete action aimed at the absurd and unjust conditions that have plagued so many Palestinians after the construction of the Wall? The strategy of rupture as developed by the French advocate Jacques Vergès (discussed at length below) was once deployed in the defence of Algerian freedom fighters and other anti-colonial nationalists charged with criminal acts by colonial authorities. This article asks whether there is some aspect of this strategy that could be generalized and applied to non-criminal law domains, such as the administrative, military, property, or constitutional legal orders that structure and buttress the occupation?

Shortly before this workshop, the Indian Supreme Court had released their judgment in Nandini Sundar et al v State of Chattisgarh. The judgment presents a highly unusual judicial intervention into one of the primary and most formidable causes of state repression of political dissent: the Court actually criticizes the capitalist development policies of the state and private sector that have impoverished the poorest inhabitants of the state, and identifies the degradation of their lives as the cause of armed resistance to the dispossession of their lands and livelihoods. The Court, in effect, shatters the illusory and unreal sovereignty of the individual who is technically and formally considered an equal member of the political community, but simultaneously subjected to untold levels of social and economic inequality in the private sphere. The Court challenges a formal equality endowed by the state, which, in concert with the private sector, exploits private

\footnotetext{
KG Kannabiran, The Wages of Impunity: Power, Justice, and Human Rights (Hyderabad, India: Orient Longman, 2003) at 10.

Online: Decolonizing Architecture Art Residency <http://www.decolonizing.ps/site/about/>.

3 Examples of these absurd and unjust conditions include portions of Palestinian homes being rendered inaccessible because they fall on the wrong side of newly drawn borders; or the new Palestinian Legislative Buildings themselves being jurisdictionally situated so as to be inaccessible to different constituencies they purportedly represent. See online: Decolonizing Architecture Art Residency <http://www.decoloni-zing.ps/site/deterritorialized-parliament/.
} 
property relations and feudal social relations of caste to degrade the lives of the poor and dispossessed in their pursuit of a neo-liberal development paradigm. Marx revealed how the emergence of formal legal equality as the defining characteristic of political citizenship in emergent constitutional democracies of the $18^{\text {th }}$ century was accompanied by the retention of multiple forms of social inequality, relegated to the private sphere. ${ }^{5}$ The very structure of rights incorporates this paradox: political inequality is abolished at the formal level yet allowed to thrive in a putatively private sphere that is separate from the political realm. ${ }^{6}$ While the post-independence constitutions of the $20^{\text {th }}$ century certainly incorporate provisions aimed at the redistribution of social and political goods, the vacuity of formal legal equality that Marx criticized so acutely has certainly materialized insofar as the private property rights of corporations and neo-liberal development policies have been upheld at the expense of the life and livelihoods of the poor in India, South Africa and elsewhere.

The Indian Supreme Court gives voice to what we know is going on all too often when rights (to protest and resist political, social and economic injustices) are justifiably limited in the name of "security" or the "public interest", or to put it another way, when political resistance is criminalized: that rights in their very conception in liberal democratic post-colonial states are already compromised by the interests of capital. As I argue in this article, this is what defines a legal strategy of rupture: a form of immanent critique ${ }^{7}$ that exposes the contradiction inherent in rights that are defined by an illusory separation of the public sphere from the private; and by doing so, illuminates how rights that appear as "real" rights are in fact, in their content, enforcement and realization too often shaped by the "particular elements" of the so-called private sphere, namely, the imperatives of capitalist development embedded in colonial modes of governance. Effecting a rupture of this kind opens a space for the re-conceptualisation of rights with an entirely different set of political and social objectives. ${ }^{8}$ Having exposed the ways in which capitalist development imperatives of the state (and by implication, the corporate sector) shape the contours of rights, and more broadly, the nature of democracy itself, a space emerges for a reconsideration of what liberty, security, and freedom might mean.

$4 \quad$ Sundar et al v State of Chattisgarh, 5 July 2011, Supreme Court of India at paras 10, 12, 13 [Sundar].

$5 \quad$ Karl Marx, "On the Jewish Question” (Deutsch-Französische Jahrbücher, 1844) online: Marxists Internet Archive <http://www.marxists.org/archive/marx/works/1844/jewish-question/>.

6 The public/private divide has of course been subjected to thorough critiques by feminist legal scholars and political theorists. Despite a long history of critique and intervention, the putative divide between public and private realms persists in the conceptual structure of constitutionally enshrined rights. More recently, private sector involvement in the systematic violation of human rights during apartheid in South Africa has been the focal point of human rights organisations and NGO's pursuing corporations for damages for their role in atrocities. See Aletta J Norval, "Writing a Name in the Sky: Critically Reading Ranciere on Democracy" (Paper delivered at University of Chicago Political Theory Workshop, March 2010), online: The Political Theory Workshop 〈http://ptw.uchicago.edu/Norval10.pdf>.

7 As articulated by Emilios Christodoulidis, "Strategies of Rupture" (2009) 20 Law and Critique 3, explored in more depth below.

8 This objective is one explicitly shared by the work of a wide range of critical legal theorists; for instance, see the work of Roberto Unger, Alan Hunt, and with specific attention to the colonial and decolonization see Upendra Baxi and Boaventura de Sousa Santos. 
The Court reconceives basic rights enshrined in the Constitution on the basis of the principles enshrined in the Preamble and the Directive Principles of the Indian Constitution, which, while not justiciable as the Court notes:

[D]irect the State to utilize the material resources of the community for the common good of all, and not just of the rich and powerful without any consideration of the human suffering that extraction of such resources impose on those who are thought to be dispossessed and disempowered. Complete justice - social, economic and political - is what our Constitution promises to each and every citizen.

Evoking these explicitly socialist principles that were intended to shape the interpretation of constitutional law in the post-independence era arguably creates a counter-current against the tendency of the Indian judiciary (and state) to reinscribe colonial techniques of political repression. An immanent critique of the paradoxes inherent in liberal democratic forms of rights must incorporate a means of rendering visible the colonial forms of governance that persist in post-colonial states and are explicitly part of the legal apparatus in colonial settler regimes. By rendering them visible, forms of political repression that are thoroughly colonial in nature can be deconstructed.

The Indian Supreme Court judgment thus provides an important instance of legal rupture. But what is the relevance of an Indian judgment to the Palestinian context? Thinking through the similarities and differences between the Indian and Palestinian contexts became imperative for the Workshop in Beit Sahour. This was aided by the memory of the deaths of two particular individuals: K.G. Kannabiran and Jawaher Abu Rahmah. On December 30th, 2010, K.G. Kannabiran, an advocate in Hyderabad, India, who had devoted his career to defending the civil liberties and democratic rights of political activists, prisoners, adivasis, dalits, and Naxalites, amongst others, had passed away. Two days later, Jawaher Abu Rahmah died of asphyxiation due to the tear gas that she had inhaled at the weekly demonstrations against the Wall in the village of Bil'in, Palestine. The news of their respective deaths appeared in local media, and travelled through virtual networks of human rights activists, lawyers, and others. The deaths of two individuals completely unknown and unrelated to one another were at the same time marked by a certain proximity; a nearness in the political conditions that each strived to transform during their lives. Both Kannabiran and Abu Rahmah contended with the conditions of colonial and capitalist violence that both Palestinians and vast swathes of the Indian populations are continually subjected to. Thinking of the lives of these two individuals opens onto a broader consideration of the historical similarities in the forms of colonial governance that the British deployed in Mandate Palestine and India, and how these forms of governance continue in contemporary India and Israel/Palestine. The affinities, if they can be called that, in the experience of colonial domination are consciously recalled at the weekly demonstrations in the village of Bil'in, like others in the

$9 \quad$ Sundar, supra note 4 at para 12. 
West Bank, where tactic of protest is non-violent, recalling Gandhian strategies of anti-colonial resistance. ${ }^{10}$

Both the sites of devastating partitions as British colonial authorities departed, Israel/Palestine and India share many things, including a British legal heritage that excelled in criminalising political dissent and resistance to the dispossession of land $^{11}$ (and the various aspects of political citizenship imbricated with property ownership). Both Israel and India have continued as independent nation states to employ and refine repressive techniques in order to effect particular topologies of dispossession. These topologies are characterised by control over the movement of people $^{12}$, the manipulation of fluid boundaries and borders ${ }^{13}$ and if one speaks of the legal dimension of a colonial topology of displacement, a refusal to define the very legal terms used to justify the detention, incarceration, and in some cases, lethal violence employed to repress those engaged in political dissent.

The transposition of spaces of exception onto the bodies of particular political subjects appears as the inverse of controlling the movement of peoples as a means of suppressing basic freedoms of expression and political dissent. The shift from control over land to control over bodies, or, the collapsing of place and body, heralds a movement from the designation of particular spaces as devoid of legal and procedural rights and fairness to the marking of particular bodies as exceptional subjects, ones for whom basic legal rights are not available. This is manifest in the Indian context by the transmission of the concept of a notified area (which demarcates an area of exception, where basic rights and entitlements need not apply) to a notified person. ${ }^{14}$ It does not matter in which jurisdiction the notified person is found; once marked as a notified person, basic rights and entitlements are waived. The designation of political subjects such as the Naxalites as notified persons alongside the concept of notified areas speaks to the complex relationship between mobility, territory, and bodies. In the Palestinian context, the control of mobility of the population through the demarcation of particular bodies as having more mobility rights than others is a primary mechanism for fragmenting the Palestinian body politic, imposing psychological distress on Palestinians, and of course maintaining control over constantly shifting borders and access to land.

10 When I attended a weekly demonstration in Bil'in in September 2010, some of the protestors had donned masks of Gandhi, emphasising their chosen tactic of non-violent protest.

11 For instance, in the Indian context, the Land Acquisition Act, 1894 is an act passed during British rule, but continues to be used by the state to dispossess people of their land, which often requires violent force. The dispossession of thousands of farmers in West Bengal (and the infamous Nandigram incident), and the continued use of this Act in other states, such as Chattisgargh, has been the subject of much criticism. This parallels in many ways the use by the Israeli government of colonial land laws enacted by the British during the Mandate era in Palestine. See Hussein Abu Hussein \& Fiona McKay, Access Denied: Palestinian Access to Land in Israel (London: Zed Books, 2003) and Zeina B Ghandour A Discourse on Domination in Mandate Palestine: Imperialism, Property and Insurgency (London: Routledge, 2010).

12 Julie Peteet, "Stealing Time" (2008) 38 Middle East Research and Information Project 14.

13 See Eyal Weizman, Hollow Land: Israel's Architecture of Occupation (London: Verso, 2012)

14 Kannabiran, supra note 1 at 80.

15 While not addressed explicitly in this paper, the question of citizenship and its place in demands for a post-colonial polity is clearly of import in thinking through legal strategies of resistance to the Occupation in Israel/Palestine. 
In India and Palestine, as elsewhere, the designation of particular places and persons as exempt from rights, procedural fairness, and other basic forms of legal protection is a technique of political repression that derives from the colonial era. Kannabiran illuminates how the post-colonial judiciary in India has essentially enacted and renewed emergency legislation on a continual basis since 1947. In the post-independence era, the liquidizing of politics and dissent happens on a continuum that stretches back to Jallianwallah Bagh, an infamous anti-colonial riot in which unarmed Indians were massacred by General Dyer. In 1975, Indira Gandhi's government passed emergency legislation ${ }^{16}$ that infamously allowed the widespread abuse of basic rights by the police and criminal justice system. Ten years later, subsequent to her assassination, the government enacted the Terrorist and Disruptive Activities (Prevention) Act, 1985 (TADA). Mirroring provisions and the spirit of the Rowlatt Acts, colonial legislation that provided for the repression of anarchical and revolutionary movements in India ${ }^{17}, T A D A$ allows the state to suspend civil liberties and detain and incarcerate individuals without charge for long periods of time. Moreover, basic procedural safeguards are eschewed in the prosecution of individuals accused under the Act. ${ }^{18}$ As Kannabiran notes, "The TADA suspect is not dealt with according to the acts he is alleged to have committed, but the politics he professes...". ${ }^{19}$ Drawing parallels with other colonial contexts, we can note that in Israel/Palestine, Israel has maintained Emergency Laws since the establishment of the Israeli state in 1948. The continual and seemingly permanent state of emergency has allowed the ongoing appropriation of Palestinian land in Jerusalem and the West Bank, and also under the aegis of security imperatives, the ongoing imprisonment of thousands of Palestinian political prisoners without charge or trial.

In addition to emergency powers, the Indian state continues to renew and reinvent colonial era legislation whose aim was to suppress anti-colonial resistance to British rule through the restriction and repression of the freedom of movement of people engaged in political action. The freedoms of association and expression are curtailed not through censorship or bans, but through the control of movement of people. Section 144 of the Criminal Procedure Code 1973 (closely modeled on the Criminal Procedure Code of 1898), to take one example, is used to prohibit the assembly of more than five people without police permission, in order to prevent annoyances or disorder, to maintain public order and security. The courts however, have refused to define the terms of "public order" and "security", because as Kannabiran notes, this would delimit the power of police; impinging on their ability to prevent and criminalise political protest through any means they deem to be necessary. ${ }^{21}$

16 For an illuminating account of the centrality of Emergency Laws to colonial modes of governance in India see Nasser Hussain, The Jurisprudence of Emergency: Colonialism and the Rule of Law (Ann Arbor, MI: University of Michigan Press, 2003).

Kannabiran, supra note 1 at 89 .

Ibid at 94.

Ibid at 92 .

20 At the time of writing, hundreds of Palestinian political prisoners are on hunger strike in Israeli prisons, protesting the practice of administrative detention (being held for long periods of time, years, without being charged with a specific offence), poor prison conditions, and other violations of their basic human rights.

21 Kannabiran, supra note 1 at 3 
The monopoly of legitimate violence held by the state is enabled by its monopoly over the definition of terms like security, public order, and the apprehension of violence in the context of political protest. The law does not define these terms nor does the law provide any guidelines to measure the force used in these contexts. ${ }^{22}$ When restrained only by the language of proportionality, the tripartite structure of government, the executive and the judiciary of a constitutional democracy that collectively supports the objectives of public order and security as necessary to the protection of the flows of capital ${ }^{23}$ can consider quite extreme forms of violence as a legally acceptable response to political protests against dispossession at the hands of multinational capital. ${ }^{24}$ We thus have a modality of criminalising dissent which includes the control of mobility and association; techniques which rely on a monopoly of the power to define the very legal terms that justify violent repression, and finally, a police force rife with systemic racism that has always targeted (depending on one's geo-political location) black, low-caste, and poor communities with impunity.

22 Kannabiran argues that “'law and order', 'public order' and 'security of the state' are powerful semantic tools" that "have never yet been defined... Discretionary powers over the life and liberty of people invariably degenerate into capricious judgments by the authority involved, with no accountability to anybody. This irresponsible use of force has become a substitute for political solutions." Kannabiran, supra note 1 at 85.

23 The criminalization of political dissent in order to protect the daily operations and activities of those involved in the finance sector has been explicitly acknowledged recently by Frankfurt authorities, who took the administrative decision to ban protests planned for 16-19 May 2012 in Frankfurt am Main, in front of the buildings of the European Central Bank. The civil disobedience was targeted at the financial agents and authorities of the Eurozone. The Frankfurt authorities decided to make the area a restricted zone which protesters would not be allowed to occupy in the interest of security and public order. When discussing the "Blockupy ban" in the Hessian State Parliament, the administrative rationale for the ban came to light: "The blockade action cannot be assessed as peaceful. To make blockades and hinder traffic with the goal of closing down the entire financial district and the everyday life of the metropolis, has to be defined as violence." (See reference below). By defining political protest against the architects and promulgators of financial austerity measures that are dispossessing some citizens of the basic conditions of survival as violent, the Frankfurt authorities effectively pre-empt and arguably, in contravention of the European Convention of Human Rights and the German Constitutional Basic Law criminalise political protest. See online: Critical Legal Thinking

<http://www.criticallegalthinking.com/2012/05/10/authorities-define-violence-as-any-restrictionof-capital-flows/ >.

24 Kettling, containment, and detention are key methods of disrupting lawful protest and penalising those engaged in political dissent in Europe. In the UK, kettling is increasingly used to quash lawful political protest and intimidate protestors. Recently upheld as a legitimate and lawful tactic by the Grand Chamber of the European Court of Human Rights, the Court does not define what constitutes an apprehension of violence so as to justify containment. Surprisingly, the Grand Chamber found that no deprivation of liberty of the four appellants in the Case of Austin and Others $v$ The United Kingdom (March 15, 2012, European Grand Chamber) had taken place, each of whom had been detained in a kettle for up to seven hours in 2001 during anti-globalisation protests, on the basis that finding that a deprivation of liberty has occurred depends on the facts of each case. In this case, police apprehension of the possibility of serious injury or even death that might result from the political protests meant that the detention of scores of protestors was a serious restriction on the movement of the appellants, but that their Article 5 right of liberty had not been engaged. Commenting on this judgment, Michael Mansfield QC writes that "quite what level of actual or perceived violence triggers a need to impose containment is indeterminate. Quite what the threshold is that has to be crossed to convert a restriction into a deprivation of liberty is entirely unclear." See Michael Mansfield, "Our right to protest is under attack", The Guardian (1 May 2012) online: Guardian Unlimited <http://www.guardian.co.uk/commentisfree/2012/may/01/right-to-protest-under-attack>. 
Thus, by way of introduction to what follows, we see that the common thread that runs through a variety of juridical terrains is the criminalisation of political dissent, and whether one has in mind the case of adivasis in India or Palestinians in Israel/Palestine, the criminalisation of political resistance to dispossession. The question posed in this article is whether the law (in the spectacular form of the trial or the judgment that ensues) holds the potential to rupture the monopoly of the state to define the terms of legitimate political dissent and resistance to dispossession and further, to interrupt the varied modes of violence it employs to protect this monopoly.

\section{STRATEGIES OF RUPTURE}

In this article, my aim is to consider the use of law as a political strategy of rupture in colonial and post-colonial nation states. The question of whether and how to use law in order to transform and potentially shatter an existing politicallegal order is one that continues to plague legal advocates in a variety of places, from Australia, to India, to Canada to Israel/Palestine. For example, the struggle for the recognition of indigenous rights in the context of colonial settler regimes has often produced pyrrhic victories. ${ }^{25}$ The question of indigenous sovereignty is ultimately quashed, and aboriginal rights are paradoxically recognised as an interest that derives from the prior occupation of the land by aboriginal communities but is at the same time parasitic on underlying Crown sovereignty; an interest that can be justifiably limited in the interests of settlement. ${ }^{26}$ Thus, the primary and inescapable question remains: how does one utilise the law without re-inscribing the very colonial legal order that one is attempting to break down ${ }^{27} \mathrm{I}$ argue that this is an inescapable dilemma; as critical race theorists and indigenous scholars have shown, to not avail ourselves of the law in an effort to ameliorate social ills, and to promote and protect the rights of oppressed minorities is to essentially abrogate one's political responsibilities. Moreover, the reality of political struggle (particularly of the anti-colonial variety) is that it is of a diffuse and varied nature, engaging multiple different tactics in order to achieve its ends.

The notion of the ruptural defence emerges from the work of Jacques Vergès, a French advocate and subject of a film by Barbet Schroder entitled Terror's Advocate. The film is as much a portrait of Vergès' life as it is a series of vignettes of armed anti-colonial and anti-imperial struggle during the decades between the late 1940s and the 1980s. I should say at the beginning that I do not perceive Vergès as a heroic figure or defender of the oppressed; we can see from his later decisions to defend Klaus Barbie, for instance, that his desire to reveal the

25 See variously, Glenn S Coulthard, "Subjects of empire: indigenous peoples and the "politics of recognition' in Canada. (2007) 6 Contemporary Political Theory 437; Brenna Bhandar "Plasticity and Post-Colonial Recognition: Owning, Knowing and Being" (2011) 22 Law and Critique 227; Jon Goldberg-Hiller, "Persistence of the Indian: Legal recognition of native Hawaiians and the opportunity of the Other" (2011) 33 New Political Science 23.

See in the Canadian context, Delgamuukw v British Columbia [1997] 3 SCR 1010.

27 Yet another problem of utilising the law for social emancipation lies in the very articulation of a rights claim on the basis of an identity defined by exclusion. As Wendy Brown has argued, "if the identity requires exclusion as its premise, then it can never be fully included within the polity or community from which it is excluded." See Wendy Brown, States of Injury: Power and Freedom in Late Modernity (Princeton, NJ: Princeton University Press, 1995) at 162. 
violence wrought by European imperial powers was pursued at any cost. But in tracing the development of what Vergès called the ruptural defence, the film takes us to the heart of the inescapable paradoxes and contradictions involved in using law as a means of political resistance in colonial and post-colonial contexts. I want to explore the strategy of rupture as developed by Vergès but also in a broader sense, to consider whether there is in this defence strategy that arose in colonial, criminal law contexts, something that is generalisable, something that can be drawn out to form a notion of legal rupture more generally.

To begin then, an exploration of Vergès' "rupture defence", or rendered more eloquently, a strategy of rupture. At the beginning of the film, Vergès comments on his strategy for the trial of Djamila Bouhired, a member of the National Liberation Front [FLN], who was tried in a military court for planting a bomb in a cafe in Algiers in 1956. Vergès states the following in relation to the trial:

The problem wasn't to play for sympathy as left-wing lawyers advised us to do, from the murderous fools who judged us, but to taunt them, to provoke incidents that would reach people in Paris, London, Brussels and Cairo... ${ }^{28}$

The refusal to play for sympathy from those empowered to uphold the law in a colonial legal order hints at the much more profound refusal that lies at the basis of the strategy of rupture, which we see unfold throughout the film. In refusing to accept the characterisation of Djamila's acts as criminal acts, Vergès challenges the very legal categories that were used to criminalise, condemn and punish anticolonial resistance. The refusal to make the defendants' actions cognisable to and intelligible within the colonial legal framework breaks the capacity of the judges to adjudicate in at least two senses. First, their moral authority is radically undermined by an outright rejection of the legal terms of reference and categories which they are appointed to uphold. The legal strategy of rupture is a politics of refusal that calls into question the justiciability of the purported crime by challenging the moral and political jurisdiction of the colonial legal order itself.

Second, the refusal of the legal categorisation of the FLN acts of resistance as criminal brought into light the contradictions inherent in the official French position and the reality of the Algerian context. This was not, as the official line would have it, simply a case of French criminal law being applied to French nationals. The repeated assertion that the defendants were independent Algerian actors fighting against colonial brutality, coupled with repeated revelations of the use of torture on political prisoners made it impossible for the contradictions to be "rationally contained" within the normal operations of criminal law. The revelation and denunciation of torture in the courtroom not to prevent statements or admissions from being admissable as evidence (as such violations would normally be used) but to challenge the legitimacy of the imposition of a colonial legal order on the Algerian people made the normal operation of criminal law procedure virtually impossible. ${ }^{29}$ And it is in this making impossible of the operation of the legal order that the power of the strategy of rupture lies.

28 Barbet Schroeder, Terror's Advocate, 2007, Documentary Film.

29 Christodoulidis, supra note 7 at 4 
In refusing to render his clients' actions intelligible to a colonial (and later imperial) legal framework, Vergès makes visible the obvious hypocrisy of the colonial legal order that attempts to punish resistance that employs violence, in the same spatial temporal boundaries where the brute violence of colonial rule saturates everyday life. As such, this is a strategy that challenges the monopoly of legitimate violence the state holds. Vergès aims to render visible the false distinction between common crimes and political crimes, or more broadly, the separation of law and politics. ${ }^{30}$ The ruptural defence seeks to subvert the order and structure of the trial by re-defining the relation between accuser and accused. This illumination of the hypocrisy of the colonial state questions the authority of its judiciary to adjudicate. But more than this, his strategy is ruptural in two senses that are fundamental to the operation of the law in the colonial settler and postcolonial contexts. The first is that the space of opposition within the legal confrontation is reconfigured. The second, and related point, is that the strictures of a legal politics of recognition are shattered.

In relation to the first point, a space of opposition is, in the view of Fanon, missing in certain senses, in the colonial context. ${ }^{31}$ A space of opposition in which a genuinely mutual struggle between coloniser and colonised can occur is denied by spatial and legal-political strategies of containment and segregation. While these strategies also exhibit great degrees of plasticity ${ }^{32}$, the control over such mobility remains to a great degree in the hands of the colonial occupier. The legal strategy of rupture creates a space of political opposition in the courtroom that cannot be absorbed or appropriated by the legal order. In Christodoulidis' view, this lack of co-option is the crux of the strategy of rupture.

This strategy of rupture also points to a path that challenges the limits of a politics of recognition, often one of the key legal and political strategies utilised by indigenous and racial minority communities in their struggles for justice. Claims for recognition in a juridical frame inevitably involve a variety of ontoepistemological closures. ${ }^{33}$ Whether because of the impossible and irreconciliable relation between the need for universal norms and laws and the specificities of the particular claims that come before the law, or because of the need to fit one's claims within legal-political categories that are already intelligible within the legal order, legal recognition has been critiqued, particularly in regards to colonial settler societies, on the basis that it only allows identities, legal claims, ways of being that are always-already proper to the existing juridical order to be recognised by the law. In the Canadian context, for instance, many scholars have elucidated the ways in which the legal doctrine of aboriginal title to land imports Anglo-American concepts of ownership into the heart of its definition; and moreover, defines aboriginality on the basis of a fixed, static concept of cultural difference. $^{34}$ The strategy of rupture elides the violence of recognition by challenging the legitimacy of the colonial legal order itself.

31

32

33

34

Jacques Vergès, De La Stratégie Judiciare (Paris: Les Éditions de Minuit, 1968) at 11.

Fanon, Black Skin, White Masks, (New York: Grove Press, 1967)

See Eyal Weizman, "Political Plastic (Interview)" (2010) 6 Collapse: Philosophical research and Development.

See Bhandar, supra note 25 and Coulthard, supra note 25.

See Bhandar, supra note 25; and John Borrows, "Frozen Rights in Canada: Constitutional

Interpretation and the Trickster" (1997/1998) 22 Am Indian L Rev 37. 
In an article discussing Vergès' strategy of rupture, Emilios Christodoulidis takes up a question posed to Vergès by Foucault shortly after the publication of Vergès' book, De La Stratégie Judiciare, as to whether the defence of rupture in the context of criminal law trials in the colony could be generalised more widely, or whether it was "not in fact caught up in a specific historical conjuncture." ${ }^{35}$ In exploring how the strategy of rupture could inform practices and theory outside of the courtroom, Christodoulidis characterises the strategy of rupture as one mode of immanent critique. As individuals and communities subjected to the force of law, the law itself becomes the object of critique, the object that needs to be taken apart in order to expose its violence. To quote from Christodoulidis:

Immanent critique aims to generate within these institutional frameworks contradictions that are inevitable (they can neither be displaced nor ignored), compelling (they necessitate action) and transformative in that (unlike internal critique) the overcoming of the contradiction does not restore, but transcends, the 'disturbed' framework within which it arose. It pushes it to go beyond its confines and in the process, famously in Marx's words, "enables the world to clarify its consciousness in waking it from its dream about itself ${ }^{36}$

Christodoulidis explores how the strategy of rupture can be utilised as an intellectual resource for critical legal theory and more broadly, as a point of departure for political strategies that could cause a crisis for globalised capital. Strategies of rupture are particularly crucial when considering a system, he notes, that has been so successful at appropriating, ingesting and making its own, political aspirations (such as freedom, to take one example) that have also been used to disrupt its most violent and exploitative tendencies. Here Christodoulidis departs from the question of colonialism to focus on the operation of capitalism in post-war European states. It is also this bifurcation that I want to question, and rather than a distinction between colonialism and capitalism, to consider how the colonial (as a set of economic and political relations that rely on ideologies of racial difference, and civilisational discourses that emerged during the period of European colonialism) is continually re-written and re-instantiated through a globalised capitalism. As I elaborate in the discussion of the Salwa Judum judgment below, it is the combination of violent state repression of political dissent that finds its origins (in the legal form it takes) during the colonial era, and capitalist development imperatives that implicate local and global mining corporations in the dispossession of tribal peoples that constitutes the legalpolitical conflict at issue.

\section{AFTER THE TRIAL: FROM DEFENCE TO JUDGMENT}

"Les bons juges, comme les héro de la presse du coeur, n'existent pas."

35 Christodoulidis, supra note 7 at 3

$36 \quad$ Ibid at 6.

37 Vergès, supra note 30 at 9. 
In response to a question from Jean Lapeyrie (a member of the Action Committee for Prison-Justice) during a discussion of De La Stratégie Judiciare published as the Preface to the second edition, Vergès remarks that there are actually effective judges, but that they are effective when forgetting the essence of what it is to be a judge. ${ }^{38}$ The strategy of rupture is a tactic utilised to subvert the order and structure of a trial; to re-define the very terms upon which the trial is premised. On this view, the judge, charged with the obligation to uphold the rule of law is of course by definition not able to do anything but sustain an unjust political order.

In the film Terror's Advocate, one is left to wonder about the specificities of the judicial responses to the strategy deployed by Vergès. (Djamila Bouhired, for instance, was sentenced to death, but as a result of a worldwide media campaign was released from prison in 1962). While I would argue that the judicial response is clearly not what is at stake in the ruptural defence, I want to consider the potentiality of the judgment to be ruptural in the sense articulated by Christodoulidis, discussed above. Exposing a law to its own contradictions and violence, revealing the ways in which a law or policy contradicts and violates rights to basic political freedoms, has clear political-legal effects and consequences. Is it possible for members of the judiciary to expose contradictions in the legal order itself, thereby transforming it? Would the redefinition, for instance, of constitutional provisions guaranteeing rights that come into conflict with capitalist development imperatives constitute such a rupture? In my view, the re-definition of the limitations on the guarantees of individual and group freedom that are inevitably and invariably utilised to justify state repression of rights in favour of capitalist development imperatives, security, or colonial settlement have the potential to contribute to the re-creation of political orders that could be more just and democratic.

We may be reluctant to ever claim a judgment as ruptural out of fear that it would contaminate the radical nature of this form of immanent critique. Is to describe a judgment as ruptural to belie the impossibility of justice, the aporia that confronts every moment of judicial decision-making? I want to suggest that it is impossible to maintain such a pure position in relation to law, particularly given its capacity (analogous to that of capital itself) for reinvention. Thus, I want to explore the potential for judges to subvert state violence engendered by particular forms of political and economic dispossession, through the act of judgment. In my view, basic rights protected by constitutional guarantees (as in the Indian case) have been so compromised in the interests of big business and development imperatives, that re-defining rights to equality, dignity and security of person, and subverting the interests of the state-corporate nexus is potentially ruptural, in the sense of causing a crisis for discrete tentacles of global capitalism.

At this juncture, we may want to explicitly account for the specific differences between criminal defence cases and Vergès' basic tactic, which is to challenge the very jurisdiction of the court to adjudicate, to define the act of resistance as a criminal one, and constitutional challenges to the violation of rights in cases such as Salwa Judum. While one tactic seeks to render the illegitimacy of the colonial state bare in its confrontation with anti-colonial resistance, the other is a tactic used to re-define the terms upon which political dissent and resistance take place

$38 \quad$ Ibid. 
within the constitutional bounds of the post-colonial state. These two strategies appear to be each other's opposite; one challenges the legitimacy of the state itself through refusing the jurisdiction of the court to criminalise freedom fighters, while the other calls on the judiciary to hold the state to account for criminalising and violating the rights of its citizens to engage in political acts of dissent and resistance. However, the common thread that situates these strategies within a singular political framework is the fundamental challenge they pose to the state's monopoly over defining the terms upon which anti-colonial and anti-capitalist political action takes place.

Here I will turn to consider a post-colonial context in which the colonial is continually being re-written, juridically speaking, in light of neo-liberal economic imperatives unleashed from the late 1980s onwards. A recent judgment of the Indian Supreme Court provides an opportunity to consider a moment in which capitalist development imperatives and the exploitation of tribal peoples by the state of Chattisgarh are put on trial by a group of three plaintiffs. The judgment provides, amongst other things, an opportunity to consider the strategy of the plaintiffs and also the judicial response. As I argue below, this judgment presents an instance of rupture precisely because the fundamental freedoms of the people of Chattisgarh are redefined by the Court in such a way as to challenge and condemn the capitalist development imperatives that have put their lives and livelihoods at risk.

\section{SALWA JUDUM}

The Indian Supreme Court rendered judgment in the case of Nandini Sundar and others $v$ the State of Chhattisgarh on July 5th, 2011. In this case, Sundar, a professor of Sociology at the Delhi University, along with Ramachandra Guha, an eminent Indian historian, and Mr. E.A.S. Sarma, former Secretary to Government of India and former Commissioner, Tribal Welfare, Government of Andhra Pradesh, petitioned the Supreme Court of India alleging, inter alia, that widespread violations of human rights were occurring in the State of Chattisgarh, on account of the ongoing Naxalite/Maoist insurgency and the counter-insurgency activities of the State government and the Union of India (or the national government). More specifically, the petitioners alleged that the State was in violation of Articles 14 and 21 of the Indian Constitution. Article 14 guarantees equality before the law, and Article 15, freedom from discrimination on the basis of race, religion, caste, sex or place of birth. Article 21 of the Constitution guarantees the protection of life and personal liberty. ${ }^{39}$

While a comprehensive overview of the Naxalbari movement is beyond the scope of this article, I provide a very brief description of the movement here, by way of explaining the political and legal background of the judgment. The Naxalites are revolutionary communists (Maoists) who split from the Communist Party of India shortly after independence. The movement includes a social base comprised of "landless, small peasants with marginal landholdings," and

39 See online: Ministry of Law and Justice <http://lawmin.nic.in/olwing/coi/coi-english/coiindexenglish.htm>. 
adivasis. ${ }^{40}$ Bhatia notes that in the state of Bihar, many people join the movement in order to pursue short-term goals, such as better education, food and housing, and employment, with revolution a distant concept if not altogether foreign to more immediate objectives of radical change. ${ }^{41}$ Regardless of whether revolution is the immediate or long-term objective of members of the Naxalite movement, it is clear that along with economic and social rights lies the desire for freedom from violence and fear in a political context described by some as semi-feudal. One young Naxalite described the hangover of feudal attitudes towards lower castes by stating "the landlord's moustache has got burnt but the twirl still remains."

With a powerful and unrelenting presence in tribal areas, arguably amongst the most impoverished parts of the country, Naxalites have engaged in nonviolent and direct armed action against state and national governments intent on pursuing capitalist modes of development at the expense of the poor, throughout nine different states in India. Specifically, the Naxals have focused on land rights, minimum wages for labourers, common property resources and housing rights. The strategy of armed resistance has met with criticism across the political spectrum, ${ }^{44}$ and it is difficult to gauge the level of support for the Naxalites amongst left and progressive communities in India. However, the ascription by India's Prime Minister Manmohan Singh to the Naxals as the "singlest greatest threat to India's national security" repression called Operation Greenhunt that has attracted criticism by political progressives.

This is the background to the petition brought by Sunder, Guha and Sarma. The petition alleged, inter-alia, the widespread violation of human rights of people of Dantewada District and neighboring areas in Chattisgarh. Specifically, the petitioners alleged that the State of Chattisgargh was supporting the activities of an armed vigilante group called "Salwa Judum" ("Purification Hunt" in the Gondi language). The State was actively promoting the Salwa Judum through the appointment of Special Police Officers [SPOs]. The government of Chattisgargh, along with the Union of India government, was alleged to have employed thousands of "special police officers" as a part of their counter-insurgency strategies. The SPOs, a category that finds its origins in colonial policing legislation, ${ }^{46}$ are members of the tribal communities, and are often minors. The SPOs, as the Court notes, are armed by the State and given little or no training, to fight the battles against the Naxalites. At the time the Court passed down its judgment, 6,500 tribal youth have been conscripted into the Salwa Judum. ${ }^{47}$ Banaji

40 Bela Bhatia, "The Naxalite Movement in Central Bihar", Economic and Political Weekly (9 April 2005) 1536-1549 at 1537. Adivasis are the tribal or indigenous peoples of India.

$41 \quad$ Ibid at 1547.

$42 \quad$ Ibid at 1542.

43 Ibid

44 For criticisms by those on the left, see e.g. Jairus Banaji, “The Ironies of Indian Maoism” (2010) 128 International Socialism online: International Socialism <http://www.isj.org.uk/?id=684\#128banaji_74>.

45 Jo Johnson, "Insurgency in India - how the Maoist threat reaches beyond Nepal", Financial Times (26 April 2006).

46 Sections 17, 18 and 19 of the Indian Police Act, 1861 provide for the appointment of SPOs.

47 Sundar supra note 4 at para 44. 
notes that the "wholesale militarisation of the movement since the 1990s has culminated in a vanguard war trapped in an expanding culture of counterinsurgency." ${ }^{48}$

The State of Chattisgargh recruits SPOs (also known as Koya Commandos) under the provisions of the Chattisgargh Police Act 2007. Under this Act, the SPOs, as the Court notes, "enjoy the "same powers, privileges and perform same duties as coordinate constabulary and subordinate of the Chattisgargh Police." ${ }^{49}$ The Union Government of India sets the limit of the number of SPOs that each state can appoint for the purposes of reimbursement of an honorarium under the Security Rated Expenditure Scheme. The State argued on its behalf that the SPOs receive two months of training covering such things as the use of arms, community policing, unarmed Combat and yoga training, and the use of scientific and forensic aids in policing. ${ }^{50}$ The Union Government argued that the SPOs "have played a useful role in the collection of intelligence, protection of local inhabitants and ensuring security of property in disturbed areas." ${ }^{51}$ Despite these attempts at a defence, the Court found in favour of the petitioners.

The Court contrasts the provisions of the 2007 Act that provide for the conditions under which the Superintendant of Police may appoint "any person" as an SPO with the parallel provisions in the British era legislation. ${ }^{52}$ They find that the 2007 Act, unlike its predecessor, fails to delimit the circumstances under which such appointments can be made. The circumstances however, do include "terrorist/extremist" incidents, and the Court thus finds that the SPOs are "intended to be appointed with the responsibilities of engaging in counterinsurgency activities." that thousands of tribal youth are being appointed by both the State and Union governments to engage in armed conflict with the Naxalites, and that this places the lives of tribal youth in "grave danger." Given that youth being conscripted have very low levels of education and are often illiterate, and that they themselves have likely been the victims of state and Naxal violence, the Court found that they could not "under any conditions of reasonableness" assume that the youth are exercising the requisite degree of free will and volition in relation to their comprehension of the conditions of counter-insurgency and the consequences of their actions, and thus, were not viewed by the court as freely deciding to join the police force as SPOs. ${ }^{55}$ After a very thorough analysis of the conditions under which tribal youths become SPOs and the use and abuse of the SPOs by the State, the Court found the State of Chattisgarh to be in violation of Articles 14 and 21 of the Constitution by appointing tribal youth as SPOs engaged in counterinsurgency.

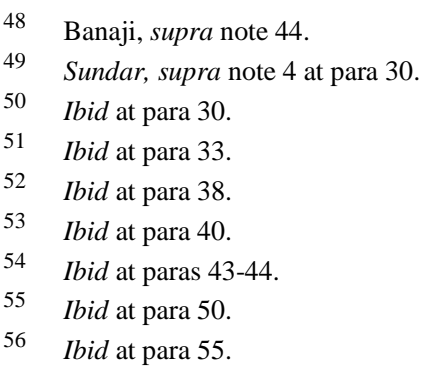


The Court's findings in relation to the SPOs are remarkable insofar as they account for the socio-economic conditions and lived realities of the tribal youth. In their judgment, however, they go much further than engaging a contextualised and nuanced approach to the interpretation of the rights to equality, life and personal liberty. They enquire into the causes of Naxalite violence, and in doing so, hold capitalist development imperatives to account; the constitutional rights of tribals and others dispossessed of their lands and livelihoods are being violated in the interests of capital. Drawing on academic work critical of globalisation, the Court quotes the following:

'[T]he persistence of "Naxalism", the Maoist revolutionary politics, in India after over six decades of parliamentary politics is a visible paradox in a democratic "socialist" India.... India has come into the twenty-first century with a decade of departure from the Nehruvian socialism to a free-market, rapidly globalizing economy, which has created new dynamics (and pockets) of deprivation along with economic growth. Thus the same set of issues, particularly those related to land, continue to fuel protest politics, violent agitator politics, as well as armed rebellion.....5

The Court recognises that the capitalist development imperatives of the state are the cause of the armed resistance when they state that the problem lies not with the people of Chattisgarh, nor those who question the conditions under which the conflict has been produced, but "[t]he problem rests in the amoral political economy that the State endorses, and the resultant revolutionary politics that it unnecessarily spawns." ${ }^{58}$ Quoting from a report written by an expert group appointed by the Planning Commission of India, the Court takes note of the "irreparable damage" caused to marginalised communities by the development paradigm adopted by the national government since independence. ${ }^{59}$ The economic development pursued has "inevitably caused the displacement" of these communities and "reduced them to a sub-human existence". 00 The Expert Group also noted their surprise at the refusal of the State to recognise the reasons for the political dissent expressed by the Naxalites, and the disruption of law and order. The Court adopts this observation, and notes that:

Rather than heeding such advice [to address the dehumanisation wreaked by capitalist development policies], which echoes the wisdom of our Constitution, what we have witnessed in the instant proceedings have been repeated assertions of inevitability [sic] of muscular and violent statecraft.

Quoting from Ajay K. Mehra "Maoism in a globalizing India" in Jorge Heine \& Ramesh Thakur eds, The Dark Side of Globalization (New York: United Nations University Press, 2011) 101 at para 5.

Ibid.

Ibid at para 6.

Ibid.

Ibid at para 8. 
Following this remarkable assertion of Constitutional values that are opposed to the state violence used to repress political dissent, the Court accounts for the violence rendered by capitalist development imperatives:

The culture of unrestrained selfishness and greed spawned by modern neo-liberal economic ideology, and the false promises of ever increasing spirals of consumption leading to economic growth that will lift everyone, under-gird this socially, politically and economically unsustainable set of circumstances in India in general, and Chattisgarh in particular."

The exploitation of natural resources violate principles that are "fundamental to governance" and this violation eviscerates the promise of equality before the law, and dignity of life (Article 21). ${ }^{63}$ Capitalist development imperatives and neoliberalism "necessarily tarnish" and "violate in a primordial sense" Articles 14 and 21 of the Indian Constitution. ${ }^{64}$ The Court thus positions the rights to equality and dignity in opposition to capitalist development imperatives, and most significantly, do not find that the violation can be justifiably limited. Economic policies that violate the spirit of the Constitution, and run counter to the "primary task of the state" which is to provide security for all of its citizens "without violating human dignity" cause levels of social unrest that ultimately amount to an "abdication of constitutional responsibilities". ${ }^{65}$ In their finding that neo-liberal ideology amongst other economic policies are the root causes of the social unrest and Naxal militancy, the Court re-values the constitutional and human rights of its citizens and asserts a radically different vision of the role of the state in promoting and protecting democracy. Based on the spirit of the Constitution as enacted at the time of independence, the Court clearly puts forth a view that the conditions for democracy begin with state protection and enhancement of human dignity and equality, education, and freedom from violence, rights and values that are contrary to the capitalist economic policies embraced by the State of Chattisgarh.

Constitutional rights claims, whether we are looking at state of the art constitutions in Canada, South Africa or elsewhere, do not often go beyond a liberal conception of rights. And indeed, utilising human rights as a means of provoking political ruptures (as opposed to ameliorating existing conditions) surely seems like a rather bankrupt endeavour, in light of how rights to freedom and liberty have been effectively co-opted by market imperatives. ${ }^{66}$ The Indian Supreme Court judgment thus seems all the more compelling, in its condemnation of developmental terrorism, and capitalist greed. The judgment finds in favour of the petitioners. In doing so, they explicitly critique the capitalist model of development that has impoverished so many millions of people. They express the view that people do not rise up in armed insurgency against the state without

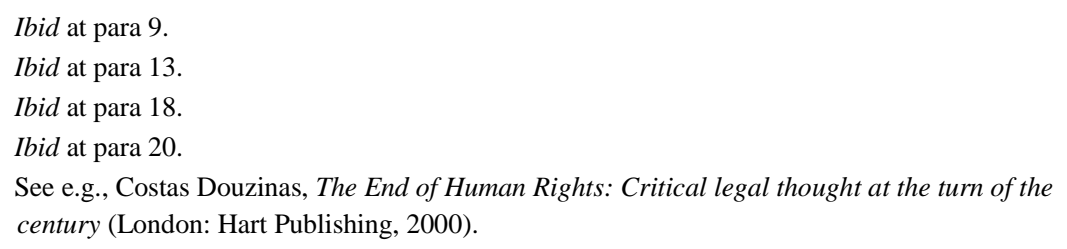


cause, and find the failure of the State to affirmatively fulfill its obligation to protect the life and liberty of the SPOs is a breach and violation of the Constitution. They find, significantly, that the very economic policies pursued by the government, coupled with the treatment of tribals as nothing more than cannon fodder in the war against the Naxalites, have dehumanised those most vulnerable to poverty. The Court adopts the words of Joseph Conrad in their condemnation of the impoverishment and exploitation of the tribals by both the state and union governments. Drawing parallels with Conrad's characterisation of the colonial exploitation of the Congo in the late 19th and early 20th centuries, the Court relates the "vilest scramble for loot that ever disfigured the history of human conscience" to the "scouring of the earth by the unquenchable thirst for natural resources by imperialist powers". 67

The Court also alludes to the virulent auto-immune reaction that exists like a germ, waiting to explode, amongst the tribal youths. With no established mechanism for getting the arms back from the tribal youths, the Court predicts the possibility of these youths becoming "roving groups of armed men endangering the society, and the people in those areas as a third front." ${ }^{68}$ They write that it is

"entirely conceivable that those youngsters refuse to return the arms Consequently, we would then have a large number of armed youngsters, running scared for their lives, and in violation of the law. It is entirely conceivable that they would then turn against the State, or at least defend themselves using those firearms, against the security forces themselves; for their livelihood, and subsistence.... ${ }^{69}$

In finding the government responsible for the socio-economic conditions that have led to revolutionary activity, and in condemning their brutal and inhumane use of tribal youth in the armed struggle against the Naxalites, (caused, in the view of the Court, by policies of privatisation that leave the state ideologically and actually incapable of dealing with the social unrest) the Court engages in an immanent critique of the political ideology and legal policies of the government. In critiquing the violence of capitalist development imperatives pursued by the state, and the inhumane violence utilised by the state to counter its natural consequences (armed unrest), the Court re-invests concepts of liberty, life, and equality with political meaning that goes beyond their usual liberal interpellations. The concept of security is reinterpreted with the interests of the poor in mind, the market logic of efficiency condemned as a guiding principle and objective of government policy.

\section{CONCLUSION}

"Security is the insurance of egoism."

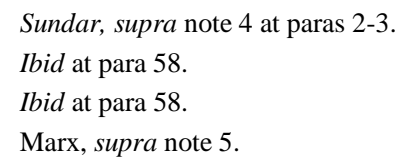


Outside of a criminal or military law context, a strategy of rupture might involve an exposure of the contradictions that inhere in colonial, capitalist legal orders that eviscerate the potentiality that rights hold to enable individuals to live lives free of fear, violence and exploitation. In considering how this rupture might occur through the act of judgment, it may be through challenging the authority of the state to engage its citizens in ways that violate political and ethical norms of freedom. In the judgment analysed here, the Court seizes the power to define the constitutional norms and crucially, the meaning of the rights to life, personal liberty and security. They engage in an act of radical re-definition of democratic rights with the lived conditions of the poorest communities at the forefront of their analysis.

In this judgment the Indian Supreme Court redefines the imperatives of security as a State obligation to its citizens, to "secure for our citizens conditions of social, economic, and political justice for all who live in India...". ${ }^{71}$ Without this, the Court notes that the State will not have achieved human dignity for its citizens. This, for the court, is an essential truth, and "policies which cause vast disaffection amongst the poor" not only exist in opposition to this truth but are also "necessarily destructive of national unity and integration". ${ }^{72}$ The Court thus identifies Indian democracy as what is at stake in the revaluing and reinterpretation of rights to life and security of the person.

In directing their analysis at the ways in which neo-liberal capitalism as a political and economic rationality "has launched a frontal assault on the fundaments of liberal democracy, displacing its basic principles of constitutionalism, legal equality, political and civil liberty, political autonomy, and universal inclusion with market criteria...", recuperate the deracinated vision of democracy that Indian corporateers and government ministers appear to have in mind. Surely, in a time when even the most basic democratic rights of vast numbers of poor and marginalized communities are not being met, when rights to education, freedom of association and movement, freedom from deprivation and dispossession are absent, charting such legal terrain opens a space for political rupture.

In considering whether legal judgments can be ruptural in the sense elucidated by Christodoulidis, and reflecting on Sundar, it is clear that an independent judiciary does have the power to disturb the monopoly of violence exercised by the government, and to transcend this disturbed framework by offering a radically different interpretation of security and freedom. Security as the insurance of egoism reflects a Benthamite definition of law's raison d'être as nothing other than the security of private property. ${ }^{74}$ The law exists in order to provide security for the property-owning classes, security for their actual wealth and also feelings of security; the law provides freedom from the fear of loss. In moving far from Benthamite concerns with the protection of private property, the Court redefines security, a concept fundamental to law's being, and more particularly, a concept too often used and abused in the interests of private corporations.

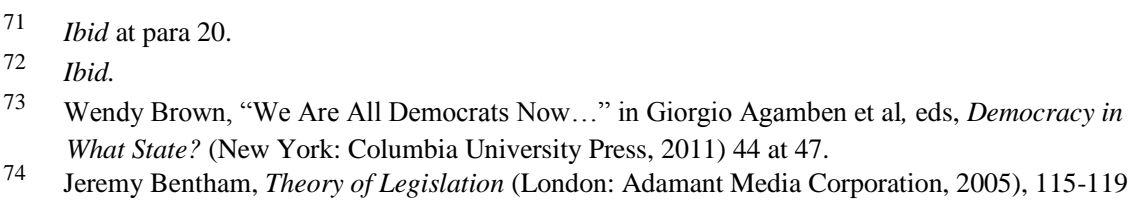


Although this use of the law does not refuse the authority of the court in the way that Vergès' strategy of rupture did in the colonial-criminal law context, it most certainly redefines the ambit of what is an intelligible rights claim. By bringing the socio-economic conditions of the adivasis and tribal peoples to the forefront of their interpretations of the rights at issue, the Court opens the space for a legal consciousness that can no longer remain caught up in a fantasy about it's own effectiveness in actually protecting the rights of the poorest and most vulnerable. This movement by the Indian Supreme Court charts an avenue that holds promise for the anti-colonial struggles of legal advocates elsewhere. 